\title{
Gambaran Penggunaan Alat Kontrasepsi pada Wanita di Indonesia
}

\author{
Fioren G. F. Rotinsulu, ${ }^{1}$ Freddy W. Wagey, ${ }^{2}$ Hermie M. M. Tendean ${ }^{2}$
}

\author{
${ }^{1}$ Program Studi Pendidikan Dokter Fakultas Kedokteran Universitas Sam Ratulangi, Manado, \\ Sulawesi Utara, Indoensia \\ ${ }^{2}$ Bagian Ilmu Kebidanan dan Kandungan Fakultas Kedokteran Universitas Sam Ratulangi, \\ Manado, Sulawesi Utara, Indonesia \\ Email: fiorenglory@gmail.com
}

\begin{abstract}
Population growth rate affects various sectors. Therefore, the National Family Planning (KB) program was established with the aim of reducing Indonesia's population growth rate. This study was aimed to obtain the description of contraception used according to contraception methods in various regions of Indonesia. This was a literature review study. Data were searched by using one database with the specified criteria, which was Google Scholar, and data collection from BKKBN application. The keywords used in literature searching were contraception use AND contraception methods AND Indonesian. After being selected by inclusion and exclusion criteria, there were 12 literatures consisting of 6 descriptive studies, 4 cross sectional studies, 1 purposive sampling study, and 1 secondary data study. The majority of literatures mentioned that contraception method mostly used in various regions of Indonesia was hormonal contraception, in this case injection. It seems that other methods such as vasectomy in males and tubectomy in females were still not preferred. In conclusion, hormonal contraception method namely injection is the mostly used in various regions of Indonesia.
\end{abstract}

Keywords: contraception use, contraception methods

\begin{abstract}
Abstrak: Laju pertumbuhan penduduk berpengaruh terhadap berbagai sektor. Program Keluarga Berencana (KB) Nasional dibuat dengan tujuan untuk menekan laju pertumbuhan penduduk Indonesia. Penelitian ini bertujuan untuk mengetahui gambaran penggunaan alat kontrasepsi menurut metode alat kontrasepsi di berbagai daerah di Indonesia. Jenis penelitian ialah suatu literature review. Pencarian data menggunakan satu database dengan kriteria yang ditentukan yaitu Google Scholar dan pengambilan data yang berasal dari integrasi aplikasi BKKBN. Kata kunci yang digunakan dalam pencarian artikel ialah Penggunaan kontrasepsi DAN Metode kontrasepsi DAN Indonesia. Hasil seleksi dengan kriteria inklusi dan eksklusi mendapatkan 12 literatur yang terdiri dari 6 penelitian deskriptif, 4 penelitian cross-sectional, 1 penelitian purposive sampling, dan 1 penelitian data sekunder. Didapatkan penggunaan metode alat kontrasepsi di berbagai daerah di Indonesia yang terbanyak ialah kontrasepsi hormonal suntik. Metode alat kontrasepsi yang masih kurang penggunaannya ialah vasektomi atau Metode Operatif Pria (MOP) dan tubektomi atau Metode Operatif Wanita (MOW). Simpulan penelitian ini ialah mayoritas penggunaan metode alat kontrasepsi di berbagai daerah di Indonesia ialah kontrasepsi hormonal suntik.
\end{abstract}

Kata kunci: penggunaan kontrasepsi, metode kontrasepsi

\section{PENDAHULUAN}

Kesehatan reproduksi merupakan hak dasar dari setiap orang yang merupakan suatu kondisi sehat menyangkut sistem, fungsi, dan proses reproduksi. Pada saat ini prioritas pelayanan kesehatan reproduksi masih dalam hal kesehatan ibu dan anak (KIA), Keluarga Berencana (KB), Kesehatan Reproduksi Remaja (KRR) dan Penanggulangan Penyakit Menular Seksual (PPMS). ${ }^{1}$ 
Pertumbuhan penduduk di Indonesia hingga saat ini terus mengalami peningkatan. Indonesia masih menduduki peringkat empat di dunia dengan laju pertumbuhan mencapai 2,6 jiwa per tahun. Pertambahan penduduk yang cepat dan tidak seimbang dengan naiknya produksi akan mengakibatkan terjadinya banyak tekanan yang berat pada berbagai sektor seperti: penyediaan pangan, sandang, perumahan, lapangan kerja, fasilitas kesehatan, pendidikan, pengangkutan, perhubungan dan sebagainya. ${ }^{2}$ Oleh karena itu, pemerintah Indonesia menerapkan program Keluarga Berencana (KB) Nasional dengan tujuan yang diharapkan ialah untuk menekan laju pertumbuhan penduduk Indonesia. ${ }^{3}$

Keberhasilan program Keluarga Berencana (KB) telah diakui secara global dan bahkan menjadi model program $\mathrm{KB}$ di negara-negara berkembang dan hal ini telah mengantar Indonesia sebagai pusat di bidang kependudukan KB dan kesehatan reproduksi. ${ }^{4}$ Keberhasilan penggunaan alat kontrasepsi ialah saat mengambil keputusan tentang pemilihan alat kontrasepsi. Pada sebuah penelitian, pemilihan alat kontrasepsi yang dianggap paling penting oleh wanita secara keseluruhan yang menjadi pertimbangan ialah efektivitas, kurangnya efek samping, dan keterjangkauan. ${ }^{5}$

Kepala Badan Kependudukan dan Keluarga Berencana Nasional (BKKBN) (2011) menyatakan jumlah penduduk di Indonesia berdasarkan hasil penduduk tahun 2010 melebihi angka proyeksi nasional sebesar 237,6 juta dengan tingkat laju pertumbuhan penduduk sekitar $1,49 \%$. Pertumbuhan jumlah penduduk di Indonesia yang meningkat begitu pesat bisa menggeser jumlah penduduk di negara Amerika pada tahun 2060, bila laju pertumbuhan penduduk di Indonesia tidak segera dikendalikan secara maksimal. Prediksi penduduk Indonesia pada tahun 2060 bila tidak dikendalikan akan mencapai 475 juta sampai 500 juta atau meningkat dua kali lipat dari kondisi penduduk yang ada saat ini. ${ }^{6}$

Jumlah peserta KB secara nasional berdasarkan pemilihan dalam pemakaian alat kontrasepsi terbanyak dipakai di antaranya ialah alat kontrasepsi suntik $29,0 \%$, pil $12,1 \%$, implant $4,7 \%$, alat dalam rahim $4,7 \%$, metode operasi wanita (MOW) $3,8 \%$, kondom $2,5 \%$, dan metode operasi pria (MOP) $0,2 \% .^{7}$

Secara nasional program KB di Indonesia lebih diarahkan pada penggunaan Metode Kontrasepsi Jangka Panjang (MKJP) dibandingkan Non Metode Kontrasepsi Jangka Panjang (NonMKJP) Sementara itu, Survei Sosial Ekonomi Nasional tahun 2012 (Susenas, 2012) memperlihatkan data penggunaan alat kontrasepsi Provinsi Jawa Timur menunjukkan masih didominasi oleh Non-MKJP dibandingkan penggunaan MKJP. ${ }^{8}$

Masyarakat diharapkan dapat memiliki pengetahuan mengenai pentingnya untuk mengikuti program keluarga berencana (KB) terutama Pasangan Usia Subur (PUS) yang dapat berpengaruh pada kondisi pertumbuhan penduduk di Indonesia. Informasi serta gambaran mengenai penggunaan alat kontrasepsi yang ada di Indonesia dapat menjadi pegangan dalam menentukan alat kontrasepsi yang tepat untuk digunakan. Berdasarkan uraian yang telah dipaparkan maka penulis tertarik untuk meneliti gambaran penggunaan alat kontrasepsi pada wanita di Indonesia.

\section{METODE PENELITIAN}

Penelitian ini berbentuk suatu literature review yang dilakukan pada bulan September-Desember 2020. Pencarian literatur melalui publikasi di satu database dengan kata kunci Penggunaan kontrasepsi DAN Metode kontrasepsi DAN Indonesia.

\section{HASIL PENELITIAN}

Dari hasil pencarian literatur didapatkan artikel sebanyak 12.800 menggunakan Google Scholar $(n=12.800)$ yang sesuai dengan kata kunci tersebut. Selanjutnya dilakukan skrining judul yang sesuai dengan topik literature review dan diperoleh 28 artikel $(\mathrm{n}=28)$. Hasil skrining judul yang tersedia abstrak dan full text terhadap 28 artikel tersebut memperoleh 12 artikel yang memenuhi kriteria $(n=12)$, yang terdiri dari enam penelitian deskriptif, empat penelitian 
cross-sectional, satu penelitian purposive sampling, dan satu penelitian data sekunder. Kajian artikel meliputi penulis jurnal beserta tahun diterbitkan, lokasi penelitian, jenis penelitian, dan hasil penelitian yang disajikan dalam bentuk tabel. Tabel 1 memper- lihatkan distribusi gambaran penggunaan alat kontrasepsi dari metode kontrasepsi kondom, pil, suntik, implan, AKDR/IUD, MOP dan MOW berdasarkan 12 artikel yang telah memenuhi kriteria penelitian.

Tabel 1. Karakteristik literatur berdasarkan penulis, tahun, lokasi penelitian, jenis, dan ringkasan hasil penelitian dari 12 jurnal yang dikaji

\begin{tabular}{lll}
\hline \multicolumn{1}{c}{ Penulis, tahun } & \multicolumn{1}{c}{ Lokasi penelitian } & \multicolumn{1}{c}{ Jenis penelitian } \\
\hline Dyah P. Paramita et al, & Dusun Cawan dan & Deskriptif kuantitatif \\
$2018^{9}$ & Ngepek, D.I Yogyakarta &
\end{tabular}

Mutia Andriani et al, Provinsi Aceh $2018^{10}$

Dwika Aldila et al, $2019^{11}$

Provinsi Nusa Tenggara Barat (NTB)

Puja et al, 2018

Hariyani S et al, $2018^{13}$

Melisa P. Sinyal et al, $2019^{14}$

RS Manado Medical Center, Sulawesi Utara

Deskriptif, Retrospektif Kec. Medan Sunggal

Desa Cikadongdong Kec. Singaparna, Jawa Barat

Kuantitatif dengan desain deskriptif
Kelurahan Tanjung Rejo

Hasil penelitian

$45.51 \%$ PUS menggunakan $\mathrm{KB}$, sebagian besar PUS menggunakan KB non MKJP $(63,1 \%)$, Penggunaan metode terbanyak ialah suntik $(44,73 \%)$ selanjutnya AKDR/ IUD $(18,42 \%)$, pil $(15,8 \%)$, implan $(10,52 \%)$, MOW $(7,9 \%)$ dan yang sedikit pengguna ialah kondom $(2,63 \%)$.

Data sekunder, Metode statistika adalah Analysis of Variance (Anova)

Terdapat perbedaan rata-rata jumlah pengguna KB di Provinsi Aceh dengan $\mathrm{p}<0,001$. Pengguna alat kontrasepsi kondom $(8,33 \%)$, pil $(35,71 \%)$, suntik $(47,04 \%)$, implan $(3,91 \%)$, AKDR/IUD $(3,69 \%)$ dan MOW (1,33\%).

Terdapat hubungan bermakna antara persepsi preferensi MKJP dan Non MKJP. Penggunaan MKJP memiliki $\mathrm{p}<0,05$. Pengguna alat kontrasepsi pil $(13,0 \%)$, suntik $(68,4 \%)$, implan $(12,0 \%)$ dan AKDR/IUD (6,6\%).

Tingkat pengetahuan wanita PUS baik 16 orang (16,3\%), cukup 71 orang $(72,4 \%)$ kurang 11 orang $(11,2 \%)$. Pengguna alat kontrasepsi kondom $(4,1 \%)$, pil $(44,9 \%)$, suntik $(24,5 \%)$, implan $(9,2 \%)$, AKDR/IUD (4,1\%) dan MOP (4,1\%).

Responden yang ikut serta program KB sebanyak $79(58,5 \%)$ dan yang tidak ikut serta program KB sebanyak 56 (41,5\%). Pengguna alat kontrasepsi kondom (1,3\%), pil (20,3\%), suntik $(48,1 \%)$, implan (2,5\%), dan AKDR/IUD $(17,7 \%)$

Alat kontrasepsi suntik yang paling banyak digunakan di RS Manado Medical Center periode JuliDesember 2018. Pengguna alat kontrasepsi suntik $(86,2 \%)$, implan (1,7\%), AKDR/IUD (12,1\%).

Pengguna kontrasepsi hormonal memiliki pengetahuan tentang 
Mardiah, $2019^{16}$

Adina N Wijayanti et al, $2018^{17}$

Mega Silvian Natalia, $2019^{18}$

Monika F. Farid et al, $2017^{(19}$

Firdy Liwang et al, $2018^{2}$
Desa Jejangkit Pasar, Kalimantan Selatan

Kec. Semanu Kab. Gunungkidul, D.I Yogyakarta

Desa Karangbong, Kab.Probolinggo, Jawa Timur

Desa Salassae, Prov. Sulawesi Selatan

UPT Puskesmas Tampak Siring 1, Bali
Deskriptif

kuantitatif,

Pendekatan total sampling

\section{Cross Sectional}

Analitik, Cross Sectional

Purposive Sampling, Wawancara langsung menggunakan lembar kuesioner.

Cross-sectional deskriptif kontrasepsi hormonal dan non hormonal yang lebih baik disbandingkan dengan pengguna kontrasepsi non hormonal. Pengguna alat kontrasepsi kondom (3,0\%), pil $(12,4 \%)$, suntik $(57,3 \%)$, implan (17,1\%), AKDR/IUD (4,7\%) dan MOP (1,7\%) serta MOW (3,8\%).

Terdapat hubungan antara sikap akseptor $\mathrm{KB}$ dan pemilihan alat kontrasepsi. Pengguna alat kontrasepsi pil $(15,0 \%)$, suntik $(72,0 \%)$, implan (10,0\%), AKDR/IUD (1,0\%) dan MOW (2,0\%).

Yang berperan memmengaruhi pemilihan jenis kontrasepsi di Kecamatan Semanu ialah faktor pekerjaan $(\mathrm{p}=0,033)$ dan pengalaman efek samping $(\mathrm{p}=0,000)$. Pengguna alat kontrasepsi pil $(34,13 \%)$, suntik $(31,71 \%)$, implan $(14,63 \%)$, serta AKDR/IUD (24,39\%).

Hasil uji chisquare didapatkan nilai signifikasi sebesar $0,001<\mathrm{p}$ $(0,05)$ yang berarti terdapat hubungan antara tingkat pendidikan PUS dengan pemilihan alat kontrasepsi. Pengguna alat kontrasepsi kondom $(0,5 \%)$, pil $(1,8 \%)$, suntik $(70,9 \%)$, implan $(14,5 \%)$, AKDR/IUD (1,9\%), MOP (1,8\%) dan MOW $(1,4 \%)$.

Menunjukkan bahwa faktor tingkat pendidikan ibu memengaruhi pemilihan metode kontrasepsi pada wanita usia Subur (WUS) di Desa Salassae. Pengguna alat kontrasepsi pil (16,0\%), suntik $(67,9 \%)$, implan $(9,9 \%)$, AKDR/ IUD $(6,2 \%)$.

Penggunaan kontrasepsi hormonal masih lebih banyak digunakan $(62,1 \%)$ dengan jenis kontrasepsi Pil KB (30,5\%) yang lebih banyak digunakan. Pengguna alat kontrasepsi kondom $(3,2 \%)$, pil $(30,5 \%)$, suntik (18,9\%), implan (12,6\%), AKDR/IUD (25,3\%) dan MOW $(9,5 \%)$

\section{BAHASAN}

Hasil kajian literatur penelitian mendapatkan bahwa mayoritas literatur menunjukkan metode alat kontrasepsi suntik yang paling banyak digunakan. Selain itu terdapat juga beberapa literatur yang menyatakan bahwa metode alat kontrasepsi pil merupa- kan yang terbanyak digunakan. Dari 12 literatur yang dikaji, untuk metode alat kontrasepsi mayoritas ialah suntik sebanyak sembilan literatur dan pil sebanyak tiga literatur. Metode alat kontrasepsi yang paling kurang dalam penggunaannya ialah kondom sebanyak lima literatur, implan tiga 
literatur, AKDR/IUD, MOP dan MOW sebanyak satu literatur, dan terdapat satu literatur yang memiliki jumlah yang sama untuk kondom dan MOP.

Dalam Penelitian Aldila et al ${ }^{11}$ di Nusa Tenggara Barat (NTB) didapatkan prevalensi penggunaan alat kontrasepsi non MKJP lebih banyak dibandingkan dengan penggunaan alat kontrasepsi MKJP. Alat kontrasepsi suntik menjadi pilihan paling banyak untuk non MKJP sedangkan untuk MKJP paling banyak akseptor memilih menggunakan implan. Hal ini menunjukkan bahwa cakupan penggunaan MKJP masih perlu ditingkatkan lagi. Data menunjukkan bahwa responden mempertahankan pilihannya sesuai dengan preferensi alat kontrasepsi yang digunakan. Hal ini terlihat pada responden yang memilih alat kontrasepsi suntik akan memiliki preferensi tertinggi terhadap alat suntik. Sebaliknya, responden yang memilih implan juga akan memiliki preferensi yang tinggi terhadap implan. Preferensi menunjukkan tingkat kesukaan konsumen terhadap suatu produk yang mengartikan bahwa konsumen merasa puas dengan produk tersebut. Dalam hal ini ialah tingkat kesukaan akseptor terhadap kepuasan alat kontrasepsi. Keputusan pembelian ialah pemilihan dari dua atau lebih alternatif pilihan keputusan pembelian, artinya bahwa seseorang dapat membuat keputusan, harus tersedia beberapa alternatif pilihan. Dalam hal ini pemilihan akseptor terkait MKJP dan non MKJP. ${ }^{11}$

Penelitian oleh Sinyal et al ${ }^{14}$ di Rumah Sakit Manado Medical Center (MMC) periode Juli-Desember 2018 menunjukkan berdasarkan hasil penelitian, sekitar $80 \%$ akseptor menggunakan metode kontrasepsi suntik, sebab metode ini dapat diandalkan, dan dapat dengan mudah kembali subur. Pada umumnya akseptor lebih memilih metode kontrasepsi suntik, karena alasan praktis yaitu sederhana, tidak perlu takut lupa, juga untuk merencanakan kehamilan, serta efektifitas yang tinggi bila penyuntikan dilakukan secara teratur dan sesuai jadwal yang telah ditentukan. Hal ini sejalan dengan penelitian Rofikoh et al ${ }^{15}$ di Desa Simpar Kabupaten Batang, Jawa Tengah.
Jenis kontrasepsi hormonal yang paling banyak digunakan yaitu suntik. Kontrasepsi suntik menurut responden merupakan alat kontrasepsi yang aman dan sangat efektif karena tidak perlu digunakan setiap hari seperti pil.

Penelitian Wijayanti et $\mathrm{al}^{17} \mathrm{di}$ daerah Kecamatan Semanu, D.I Yogyakarta melaporkan penggunaan kontrasepsi suntik merupakan kontrasepsi yang paling banyak digunakan di antara kontrasepsi yang lain yaitu sebanyak 57\%, pil 17\%, IUD 20\% dan implan 6\%. Tetapi, penggunaan alat kontrasepsi mengalami perubahan dari yang sebelumnya dengan alasan pada penggantian terbanyak yaitu mengalami efek samping pada penggunaan kontrasepsi sebelumnya sehingga setelah mengalami penggantian, kontrasepsi pil menjadi yang paling banyak digunakan dengan jumlah $34,13 \%$ diantara kontrasepsi lainnya yaitu suntik $31,71 \%$, IUD $23,39 \%$ dan implan 14,63\%. Faktor pengalaman efek samping memiliki hasil $\mathrm{p}$ $=0,000 \quad(p<0,05)$, yang artinya terdapat hubungan antara pengalaman efek samping dengan pemilihan jenis kontrasepsi. Responden yang pernah mengalami efek samping pada penggunaan jenis kontrasepsi sebelumnya, akan beralih pada jenis kontrasepsi yang dilihat lebih aman dan nyaman digunakan.

Berdasarkan hasil yang didapatkan dari data aplikasi BKKBN pada bulan September tahun 2020 mengenai gambaran jumlah penggunaan dan persentase metode alat kontrasepsi dari 34 Provinsi di Indonesia, didapatkan metode alat kontrasepsi yang paling banyak diminati ialah suntik dengan jumlah pengguna terbanyak di Provinsi Jawa Barat yaitu 3.853.630, selanjutnya metode alat kontrasepsi yang diminati ialah pil dengan jumlah pengguna 1.684.519 di Provinsi Jawa Barat; metode alat kontrasepsi IUD/AKDR sebanyak 838.635 pengguna di provinsi Jawa Barat; metode alat kontrasepsi implan sebanyak 692.594 terbanyak di provinsi Jawa Timur; metode alat kontrasepsi MOW sebanyak 288.838 di provinsi Jawa Timur; metode alat kontrasepsi kondom dengan jumlah 158.281 di provinsi Jawa Barat; dan yang terakhir 
metode alat kontrasepsi yang paling kurang diminati ialah MOP dengan jumlah pengguna terbanyak di provinsi Jawa Barat yaitu $34.937 .{ }^{20}$

Hasil yang didapatkan dari data aplikasi BKKBN pada bulan Oktober tahun 2020 mengenai gambaran jumlah penggunaan dan persentase metode alat kontrasepsi dari setiap kabupaten/kota di Sulawesi Utara menunjukkan bahwa yang paling banyak diminati ialah suntik tetapi untuk daerah Kepulauan Talaud berbeda yaitu alat kontrasepsi yang paling banyak diminati ialah implan dan untuk Kepulauan Sitaro alat kontrasepsi yang paling diminati ialah Pil. Selanjutnya, untuk metode alat kontrasepsi di setiap daerah kabupaten/kota provinsi Sulawesi Utara yang paling sedikit pengguna ialah MOP. ${ }^{20}$

\section{SIMPULAN}

Penggunaan metode alat kontrasepsi di berbagai daerah di Indonesia yang terbanyak ialah kontrasepsi hormonal yaitu suntik. Metode alat kontrasepsi yang masih kurang penggunaannya ialah vasektomi (Metode Operatif Pria/MOP) dan tubektomi (Metode Operatif Wanita/MOW).

Disarankan untuk pengembangan program Keluarga Berencana (KB) oleh BKKBN dalam hal mengevaluasi setiap kendala di daerah-daerah di Indonesia terkait penggunaan alat kontrasepsi serta sosialisasi lanjut mengenai berbagai macam metode alat kontrasepsi agar masyarakat dapat lebih mengetahui mengenai metode alat kontrasepsi yang ada, termasuk MKJP yaitu MOP dan MOW serta IUD/AKDR.

\section{Konflik Kepentingan}

Penulis menyatakan tidak terdapat konflik kepentingan dalam studi ini.

\section{DAFTAR PUSTAKA}

1. Hasanah H. Pemahaman kesehatan reproduksi bagi perempuan: sebuah strategi mencegah berbagai resiko masalah reproduksi remaja. Sawwa J Stud Gend. 2017;11(2):229.

2. Liwang F, Bhargah A, Kusuma IBH, Prathiwindya GG, Indaya IG, Putra $S$, et al.
Gambaran penggunaan kontrasepsi hormonal dan non hormonal di wilayah kerja UPT Puskesmas Tampak Siring 1. Intisari Sains Medis. 2018;9(3):41-6.

3. Setiawati E, Handayani OWK, Kuswardinah A. Pemilihan kontrasepsi berdasarkan efek samping pada dua kelompok usia reproduksi. Unnes J Public Health. 2017;6(3):167.

4. Di S, Jawa P, Dan T, Kalimantan P, Penelitian P, Keahlian B, et al. Dalam Penyelenggaraan Kesehatan Reproduksi The Role of Local Government in the Implementation of Reproductive Health 2018;1-16.

5. Fatoni Z, Astuti Y, Seftiani S, Situmorang A, Widayatun NFN, Purwaningsih SS. Implementasi kebijakan kesehatan reproduksi di Indonesia: sebelum dan sesudah reformasi. Jurnal Kependudukan Indonesia (JKI). 2015;10(1):65.

6. Munandar B. Peran informasi keluarga berencana pada persepsi dalam praktik keluarga berencana. J Swarnabhum. 2017;2(1):51-9.

7. Suryanti Y. Fakto-faktor yang berhubungan dengan penggunaan metode kontrasepsi jangka panjang wanita usia subur. Jambura J Health Sci Res. 2019;1(1): 20-9.

8. Sumartini, Indriani D. Kesehatan F, Universitas M. Pengaruh Keinginan Pasangan Usia Subur (PUS) dalam Penggunaan Metode Kontrasepsi Jangka Panjang. Jurnal Biometrika dan Kependudukan. 2016;5(1):27-34

9. Paramita DP, Zuliyati IC. Analisis penggunaan kontrasepsi pada PUS di Dusun Cawan dan Ngepek, Argodadi, Sedayu Bantul. Proceedings of the Conference on Multidisciplinary Research in Health, 2019.

10. Andriani M, Anwar S. Analisis penggunaan metode kontrasepsi pada pasangan usia subur (PUS) di Provinsi Aceh Tahun 2016. Sriwij J Med. 2018;1(2):75-83.

11. Aldila D, Damayanti R. Persepsi terhadap alat kontrasepsi dengan keputusan penggunaan MKJP dan NonMKJP. Hasanuddin J Midwifery. 2019;1(2):58-65.

12. Puja, Elizabeth S, Dina K. Gambaran pengetahuan wanita pasangan usia subur tentang metode keluarga berencana modern di Kelurahan Tanjung Rejo 
Kecamatan Medan Sunggal tahun 2017. J Kedokt Methodist. 2018;11(1):26-30.

13. Sulistyoningsih H, Hawa AB. Gambaran partisipasi pasangan usia subur dalam program keluarga berencana di Desa Cikadongdong Kecamatan Singaparna tahun 2018. J Chem Inf Model. 2018; 53(9):1689-99.

14. Sinyal MP, Bataha Y. Penggunaan alat kontrasepsi oleh akseptor di Rumah Sakit Manado Medical Center Periode Juli-Desember 2018. J Keperawatan. 2019;7(1):1-7.

15. Rofikoh, Widiastuti YP, Istioningsih. Gambaran tingkat pengetahuan pasangan usia subur tentang kontrasepsi hormonal dan non-hormonal. Jurnal Ilmiah STIKES Kendal. 2019;9(3):197-206.

16. Mardiah. Hubungan pengetahuan dan sikap akseptor KB dengan pemilihan alat kontrasepsi di Desa Jejangkit Pasar Kecamatan Jejangkit Kabupaten Barito
Kuala. J Educ Nursing(Jen). 2019;2(1): 85-94.

17. Wijayanti AN, Febrianti Y, Estiningsih D. Faktor-faktor yang mempengaruhi pemilihan jenis kontrasepsi pada wanita usia subur Di Kecamatan Semanu Kabupaten Gunungkidul Yogyakarta. Media Farm J Ilmu Farm. 2018;113--1.

18. Natalia MS. Hubungan Tingkat pendidikan pus dengan pemilihan alat kontrasepsi di Desa Karangbong. J Chem Inf Model. 2019;53(9):1-15.

19. Farid MF, Gosal FA. Faktor-faktor yang mempengaruhi pemilihan metode kontrasepsi pada wanita usia subur (WUS) di Desa Selassae Kecamatan Bulukumpa Kabupaten Bulukumba Provinsi Sulawesi Selatan. JST Kesehat. 2017;7(4):381-8.

20. Integrasi Aplikasi BKKBN. Available from: http://aplikasi.bkkbn.go.id/ 